\title{
WODA ŚWIĘCONA (POBŁOGOSŁAWIONA) JAKO WYRAZ POWSZECHNEGO KAPKAŃSTWA WIERNYCH
}

Woda pobłogosławiona ('święcona) ${ }^{1}$ używana jest w Kościele od pierwszych wieków. ${ }^{2} \mathrm{~W}$ naszej epoce jej znaczenie wydaje się mniej rozumiane. Poniższy artykuł stanowi próbę ukazania znaczenia wody święconej dla człowieka świeckiego, który, otrzymując sakrament chrztu i związane z nim powszechne kapłaństwo, jest powołany do świętości, aby realizować ją, żyjąc w świecie. Pomagając w pełniejszym przeżyciu Eucharystii, woda święcona ma znaczenie oczyszczające, stanowi również ochronę wiernego przed niszczycielskim i szkodliwym działaniem szatana, służy też umocnieniu wiary i niesieniu duchowej pociechy.

1 W typicznych wydaniach ksiąg liturgicznych występuje wyrażenie aqua benedicta. W polskich tłumaczeniach używany jest na ogół termin „woda święcona” lub „woda poświęcona”, choć zdarza się także tłumaczenie „woda pobłogosławiona”; por. M. S a j, Woda święcona czy pobłogosławiona? Analiza prawno-liturgiczna, Prawo kanoniczne t. 59 (2016) z. 2, s. 59-72. W swoim artykule używam obu tych określeń w sposób wymienny.

2 W Euchologionie (IV-V w.) egipskiego biskupa Serapiona z Thmuis spotykamy błogosławieństwa oleju i wody podczas mszy św. Konstytucje apostolskie (IV w.) wspominają o specjalnych modlitwach poświęcenia. Liber Pontificalis wskazuje na użycie wody święconej do pokropienia mieszkań w Rzymie w VI w. Papież Leon IV w IX w. polecił, by każdy kapłan w każdą niedzielę błogosławił wodę w kościele i kropił nią wiernych. Por. T. C a r s o n, J. C e r r i to (red.), New Catholic Encyclopedia, t. 14, Detroit 2003², s. 660-662; W. K a s p e r (wyd.), Lexikon für Theologie und Kirche, t. 10, Freiburg 2006, kol. 986-987; J. N o w a k, Woda święcona, Roczniki teologiczne t. LII (2005) z. 8, s. 389; B. N a d ol s k i, Woda, w: E. Gig i l e w i c z (red.), Encyklopedia Katolicka, t. XX, Lublin 2014, s. 833-834; W i g i 1 i u s z, Odpowiedź na list biskupa Profuturusa z Bragi, w: M a r c i n z B r a g i, Dzieła, Ad fontes 6, Kęty 2008, s. 377. 


\section{Woda święcona w perspektywie teologii sakramentu chrztu}

Niedzielne pokropienie wodą święconą przed mszą św. jest przypomnieniem chrztu, przez który otrzymaliśmy udział w zmartwychwstaniu Pana. Przeżegnanie się wodą święconą z kropielnicy ustawionej w progu świątyni jest również przypomnieniem o chrzcie jako wewnętrznym oczyszczeniu i wejściu do społeczności Kościoła. W liturgii Wigilii Paschalnej wierni powtarzają obietnice składane przy chrzcie. ${ }^{3}$ Katechizm Kościoła Katolickiego ukazuje pokropienie wodą święconą, występujące często w sakramentaliach, jako znak przypominający chrzest (KKK 1668). Podkreśla, że każda świątynia, przez dostępność wody święconej, powinna sprzyjać pamięci o obietnicach chrzcielnych (KKK 1185). ${ }^{4}$ Znaczenie wody chrztu podkreśla Tertulian: „My (...) rybki zgodnie z naszym Ichtys Jezusem Chrystusem rodzimy się w wodzie i nie możemy się inaczej zbawić, jak tylko przebywając w wodzie". ${ }^{5}$ Przypomnienie o chrzcie oznacza wdzięczność Bogu za wielkie dzieło, jakiego dokonał w naszym życiu, radość bycia chrześcijaninem, poczucie wielkiej wartości chrześcijańskiego życia, ale także zobowiązanie.

Woda pomaga dostrzec w chrzcie św. nowe stworzenie. Jak Duch Święty, unosząc się nad wodami, wyprowadzał z nich otaczające nas stworzenia, tak też, unosząc się nad wodami chrztu św., wyprowadza z nich chrześcijańskie narody. Dzisiaj społeczny, a tym bardziej narodowy, wymiar sakramentu chrztu wydaje się słabiej dostrzegalny.

Woda była wielokrotnie narzędziem działania Boga w historii zbawienia. Stary Testament ukazuje przejście Izraelitów przez Morze Czerwone, wytryśnięcie wody ze skały Horeb, przejście Jordanu. Wodą posługuje się Chrystus w swoim dziele zbawienia człowieka. Dostrzegamy ją przy chrzcie w Jordanie, godach w Kanie Galilejskiej, powołaniu apostołów, nawróceniu Samarytanki, uleczeniu

3 Por. W. G r a n a t, Sakramenty święte, cz. II: Chrzest-Bierzmowanie-Pokuta, Dogmatyka katolicka VIII, Lublin 1966, s. 140.

4 Por. Katechizm Kościoła Katolickiego, Poznań 2002.

5 Te r t u li a n, Wybór pism, Warszawa 1970, PSP t. 5, s. 132 (De baptismo 1). 
sparaliżowanego przy sadzawce, przywróceniu wzroku ślepemu od urodzenia. ${ }^{6}$ Te teksty Pisma Świętego pomagają dostrzec w wodzie miejsce działania Boga, który przychodzi zbawić człowieka.

Przypomnienie o sakramencie chrztu ma szczególne znaczenie ze względu na charakter sakramentalny (pieczęć). Chrzest jest sakramentem, który może być źródłem łaski Bożej nie tylko w chwili jego przyjęcia, ale również podczas całego życia doczesnego. Żegnając się wodą święconą, możemy prosić, by chrzcielna pieczęć wydała nowe owoce w naszym chrześcijańskim życiu.

\section{Pomoc w pełniejszym przeżyciu Eucharystii}

Warto dostrzec znaczenie przeżegnania się wodą święconą przy wejściu do kościoła. Przez akt wiary uświadamiamy sobie naszą obecność w domu Bożym, nasze przychodzenie do niego nie w celu spędzenia wolnego czasu, rozmów z innymi czy przeżyć estetycznych, ale aby spotkać się z Chrystusem obecnym w Najświętszym Sakramencie i wraz z aniołami oddać cześć samemu Bogu.?

Znak krzyża, uczyniony przy wejściu do świątyni wodą pobłogosławioną, przypomina nam nasze powołanie do kultu wypływające z otrzymanego w sakramencie chrztu wprowadzenia w kapłaństwo powszechne. Ten sam gest, wykonany przy opuszczaniu świątyni, przypomina o zadaniach wynikających z bycia chrześcijaninem, o potrzebie dawania świadectwa w świecie. ${ }^{8}$

\section{Znaczenie oczyszczające}

Obmycia rytualne występują w wielu religiach, m.in. w hinduizmie, w kultach misteryjnych, w islamie. U Żydów obmycia rytualne miały na celu uwolnienie od nieczystości związanej m.in.

6 Por. J. J. G a u m e, Woda święcona w XIX wieku, Warszawa 1872, s. 75, 126n.

7 Por. J. B a d e n i (zebr.), Kazania Ks. Karola Antoniewicza, t. 3: Kazania świąteczne, Kraków 1906, s. 295n.

8 Por. J. Now a k, Woda święcona, s. 396. 
z kontaktem z ciałem zmarłego (Lb 19,10-13), dotknięciem padliny zwierząt (Kpł 11), chorobami skóry (Kpł13). Jedne praktyki przewidywały całkowite zanurzenie, inne obmycie rąk, nóg, twarzy, jeszcze inne tylko pokropienie. Już jednak w Starym Testamencie prorocy wskazywali na znaczenie oczyszczenia wewnętrznego, odzyskania czystości serca, przemiany moralnej i religijnej (Iz 1,16, Ez 36,25, Za 13,1). Chrystus Pan piętnował formalizm obmyć pozbawionych ducha (Mt 23,25). ${ }^{9}$

Rozważając opowiadanie o potopie (Rdz 6-8), możemy dostrzec, jak Bóg za pomocą wody usuwa występki. Święty Piotr nawiązuje do tego starotestamentalnego tekstu, ukazując tajemnicę chrztu św. oczyszczającego z grzechu (1P 3, 20-21).

O oczyszczającym znaczeniu w porządku nadprzyrodzonym wody, która posłużyła do chrztu, pisze św. Ambroży (†397): „O wodo, która zasłużyłaś sobie stać się sakramentem Chrystusa, która wszystko obmywasz, nie będąc sama obmyta! Od ciebie zależy początek, od ciebie koniec, a raczej ty sprawiasz, iż końca nie znamy". ${ }^{10}$ Święty Cyprian ( $\left.† 258\right)$ zachęca, by woda, która posłuży do chrztu, została wcześniej pobłogosławiona przez kapłana. ${ }^{11} \mathrm{O}$ mocy oczyszczania wody pobłogosławionej przez biskupa lub prezbitera wspominają Konstytucje apostolskie, przekazując również tekst modlitwy błogosławieństwa. ${ }^{12}$

Żegnanie się wodą święconą stanowi sakramentaliom - błogosławieństwo Kościoła, które umożliwia gładzenie grzechów

9 Por. S. J a n k o w s k i, Chrzest-historia, praktyka, znaczenie, Studia Wrocławskie 19/2007, s. 106-108.

10 Św. A m b r o ż y, Wykład Ewangelii wedtug św. Łukasza, X, 48, PSP t. 16, Warszawa 1977, s. 422.

11 „,...woda, aby mogła obmyć grzechy człowieka przyjmującego chrzest, musi być najpierw oczyszczona i uświęcona przez kapłana...”; Św. C y p r i a n, Listy, tłum. W. S z o łd r s k i, PSP 1, Warszawa 1969, s. 250 (Epistula 70, 1).

12 Por. A. B a ro n, H. P i et r a s (oprac.), Konstytucje apostolskie, Kraków 2007, s. 257-258 (Constitutiones apostolorum VIII, 29). 
powszednich przez budzenie w sercu człowieka skruchy. ${ }^{13}$ Powinna towarzyszyć mu modlitwa będąca wyrazem żalu za grzechy: „Przez to święte pokropienie, Boże odpuść me zgrzeszenie..."14

Święty Tomasz z Akwinu (†1274) uważa, że sakramentalia, w szczególności pokropienie wodą święconą, uwalniają od winy za grzechy powszednie, ale nie zawsze całkowicie usuwają powinność kary. Stopień odpuszczenia kary doczesnej za grzech zależy od gorliwości przyjmujących sakramentalia. ${ }^{15}$

W wejściu Chrystusa w wody Jordanu, na początku publicznej działalności, można dostrzec błogosławieństwo wody, która odtąd, ulegając uszlachetnieniu, może gładzić grzechy powszednie. Już w Starym Testamencie patriarchowie, Mojżesz czy prorocy, używali wody do oczyszczenia. Mojżesz, schodząc z góry Synaj z tablicami Prawa, zmieszał wodę z krwią ofiar i pokropił nią lud, by go przygotować na przyjęcie Prawa (Hbr 9,19). Aaron i jego synowie, przed wprowadzeniem w czynności kapłańskie przez Mojżesza, zostali obmyci wodą (Wj 29,4).

Współczesny świat można porównać do szpitala przepełnionego chorymi. My, ludzie Kościoła, żyjąc w świecie, jesteśmy dotknięci wieloma chorobami ducha: rozproszeniem umysłu, zajęciem drobiazgami życia, niestałością, ociężałością, odrętwieniem wobec Boga. Sakramentalia, a w szczególności woda święcona, są lekarstwem na trąd grzechu powszedniego. Grzechy te nie są czymś nieistotnym. Stanowią bowiem źródło cierpień w wymiarze osobistym i społecznym zarówno w życiu doczesnym, jak i w procesie oczyszczenia po śmierci. Sakramentalia stanowią środek zabezpieczenia przed tymi cierpieniami, który, szczególnie w świecie tak bardzo lękającym się cierpienia, powinien być chętnie przyjmowany. ${ }^{16}$

13 Por. J. P e 1 c z a r, Życie duchowe, czyli doskonałość chrześcijańska wedtug najcelniejszych mistrzów duchownych, t. I, Kraków 1886, s. 184.

$14 \mathrm{~K}$. G a w roń s k i, Jasny i gruntowny wykład prawd wiary i moralności chrześcijańskiej, Kraków 1892, s. 420.

15 Por. Św. Tom as z z A k w in u, Suma teologiczna, III, q. 87, a. 3, ad 3, t. 29: Sakrament pokuty, London 1969, s. 69.

16 Por. J. J. G a u m e, Woda święcona w XIX wieku, s. 59-63, 104-105. 
Arcybiskup Warszawy, Antoni Fijałkowski $(\uparrow 1861)$, promotor ruchu trzeźwościowego w Królestwie Polskim, nakazywał duchownym, by osobom, spowiadającym się z grzechu pijaństwa i przyrzekającym trzeźwość, dawać do ucałowania krzyż oraz pokropić je wodą święconą. ${ }^{17}$ Wydaje się, że woda święcona może być pomocą także dla współczesnego człowieka w wyzwalaniu ze złudzeń, w szczególności z nałogu alkoholizmu czy narkomanii. Woda przypomina człowiekowi jego związek z rzeczywistością, ze światem stworzonym przez Boga.

\section{Obrona przed działaniem złego ducha}

Euchologion Serapiona ukazuje wodę święconą jako ochronę wiernego przed działaniem szatana i stanowi świadectwo spożywania jej w czasach patrystycznych: „Udziel im [wodzie i olejom] łaski leczniczej mocy, aby przez wypicie i namaszczenie została oddalona wszelka gorączka, wszelki demon i wszelka choroba i aby ich przyjęcie stało się środkiem leczniczym i środkiem do zyskania pełni zdrowia, w imię Jednorodzonego Twego Jezusa Chrystusa, przez którego Tobie chwała i panowanie w Duchu Świętym przez wszystkie wieki wieków. Amen". ${ }^{18}$

Epifaniusz z Salaminy (†403) opisuje historię Józefa, człowieka świeckiego, nawróconego Żyda, który podczas budowy kościoła w Tyberiadzie przeżywał ogromne trudności związane z działaniami przeciwników i posłużył się wodą pobłogosławioną jako obroną wobec praktyk magicznych. ${ }^{19} \mathrm{~W}$ apokryfie Dzieje Piotra, którego pierwotna wersja powstała prawdopodobnie w II w. w środowisku

17 Por. K. M i k o s z e w s k i, Kazania o pijaństwie, Warszawa 1862, s. 36-37.

18 A. B a ro n, H. P i etra s (oprac.), Konstytucje apostolskie, s. 310 (Euchologion Serapiona 17,2).

19 „Wziął to naczynie z wodą na oczach wszystkich (...) nakreślił własnym palcem na naczyniu znak krzyża i głośno powiedział: «W imię Jezusa Nazarejczyka, którego ukrzyżowali ojcowie moi, i wszystkich tu obecnych, niech będzie w tej wodzie moc dla unieważnienia wszelkich czarów i magii...». I wziął wodę do ręki, i pokropił każdy piec. Działanie czarów zostało przerwane i na oczach wszystkich 
syryjskim, znajdujemy opowieść o Marcellusie. Miał on oczyścić dom, w którym przebywał Szymon Mag przez pokropienie go wodą i przyzwanie imienia Jezusa. ${ }^{20}$

Święta Teresa od Jezusa (†1582) zwierza się ze swoich cierpień związanych z napaściami złego ducha, który próbuje przeszkodzić jej w modlitwie wstawienniczej za innych, wzbudzić lęk i niepokój. Ogromną pomocą w tej sytuacji jest dla niej woda święcona: „Z wielokrotnego doświadczenia przekonałam się, że na bezpowrotne odpędzenie czartów nie ma skuteczniejszego sposobu nad święconą wodę; przed znakiem krzyża także uciekają, ale znowu wracają (...) wielka jest moc wody święconej”. ${ }^{21}$ Święty Alfons Liguori (†1787) zachęca zmagających się z pokusami złego ducha do częstego używania znaku krzyża świętego oraz żegnania się wodą święconą przy udaniu się na spoczynek, a nawet kropienia nią posłania. ${ }^{22}$ Bernadetta Soubirous ( $† 1879)$, niepewna początkowo, co do autentyczności objawień w Lourdes, bierze ze sobą wodę święconą, pokrapiając nią w kierunku ukazującej się Pani i mówiąc: „Jeśli przybywasz Pani z piekła - przepadnij, a jeśli z nieba - pozostań, proszę". ${ }^{23}$

Zwyczajnym i najczęstszym działaniem złego ducha jest pokusa. Dlatego chrześcijanin powinien bez zwłoki skorzystać ze święconej wody w sytuacji gwałtownej pokusy czy to w ciągu dnia, czy podczas bezsennej nocy. Życie chrześcijanina jest duchową walką, w której warto skorzystać z otrzymanej broni. Jedną z nich jest

ogień buchnął płomieniem"; E pi fan i u s z z Sala m iny, Panarion, Herezje 1-33, Kraków 2015, s. 367 (Contra haereses, 30, 12, 6-8).

20 „Zaczerpnąłem wody i wzywając święte imię Jezusa Chrystusa, wraz z innymi jego sługami, którzy do niego należą, pokropiłem cały mój dom, wszystkie pokoje jadalne i wszystkie kolumnady aż poza drzwi wejściowe...”; M. S t a r o w i e y s k i (red.), Apokryfy Nowego Testamentu. Apostołowie, cz. I, Kraków 2007, s. 505.

${ }_{21}$ Św. Ter e s a od Je z u s a, Dzieła, t. I, Kraków 1987, s. 388-389 (Księga życia, rozdz. 31, p. 4).

22 Por. św. A lfon s Ligu or i, Przewodnik spowiednika, Warszawa 1905, s. 166.

23 G. S c h a r f, Fatima wciąż aktualna. Orędzie i jej zwiastuni, Poznań 1994, s. 72. 
woda święcona. Nie powinna być ona orężem, któremu pozwalamy rdzewieć.

Niekiedy ludzie udręczeni są przez złego ducha, który w różny sposób ich straszy, wprowadza zamieszanie, zakłóca równowage istotną dla ludzkiego zdrowia. Cenną pomocą dla chrześcijan przeżywających takie sytuacje jest pomoc świętych, znak krzyża świętego i woda święcona. ${ }^{24}$

Rene Laurentin (†2017) wskazuje na znaczenie sakramentaliów w obronie przed działaniem Złego. W szczególności zwraca uwagę na skuteczność wody święconej (z solą), szczególnie gdy przed poświęceniem została poddana rytuałowi egzorcyzmów. „Uznano sakramentalia za zdezaktualizowane, jednak ci, którzy przeżywają walkę duchową, odkrywają dziś ich użyteczność. Tam, gdzie poszły one w zapomnienie, wielu katolików szuka ich poza Kościołem". 25 Tradycyjnie przy błogosławieniu wody dodawano do niej odrobinę soli. Ten zwyczaj nawiązuje do uzdrowienia źródła wody, jakiego dokonał w Jerychu prorok Elizeusz (2Krl 2, 19-22). ${ }^{26}$ Istnieją źródła potwierdzające użycie wody święconej z solą do pokropienia mieszkań w Kościele rzymskim już w VI w. ${ }^{27}$ Współcześnie dodawanie soli nie jest uznawane za konieczne, ale jest możliwe w myśl dotychcza-

24 Por. J. J. G a u m e, Woda święcona w XIX wieku, s. 56-58, 276, 283, 348.

25 R. L a u re n t i n, Szatan mit czy rzeczywistość? Warszawa 1997, s. 189. Nieco zaskakujący wydaje się brak wzmianki w odnowionym Rytuale Rzymskim o możliwości korzystania z wody święconej przez świeckich; por. Rytuat Rzymski. Egzorcyzmy i inne modlitwy błagalne, Katowice 2002, s. 94-104.

26 Por. M. D y b o w s k i, Sakramentalia, Poznań 1956, s. 65.W dawnej liturgii zwykła woda święcona używana była z dodatkiem soli. Święcenia dokonywał kapłan w każdą niedzielę, egzorcyzmując i błogosławiąc osobno sól i wodę, a następnie sypiąc trzykrotnie sól do wody w formie krzyża. Innym rodzajem wody święconej była tzw. woda gregoriańska używana przez biskupa do konsekracji kościoła. W jej skład obok wody i soli wchodził także popiół i wino; por. M. N o w o d w o r s k i (red.), Encyklopedia kościelna, t. 32, Płock 1913, s. 117. Istniał też osobny rodzaj wody święconej, jaką była woda chrzcielna, w której rozpuszczano olej katechumenów i krzyżmo święte.

27 Por. M. O żóg, H. P i e tr a s (oprac.), Księga Pontyfików 1-96 (do roku 772), Kraków 2014, s. 20 (Liber pontificalis, 7). 
sowej tradycji. W modlitwie poświęcenia soli kapłan prosi, by Duch Święty strzegł wiernych od napaści złego ducha. ${ }^{28}$

\section{Umocnienie wiary i duchowa pociecha}

Blaise Pascal (†1662) widzi w wodzie święconej pomoc w przyjęciu wiary przez człowieka poszukującego, pełnego wątpliwości, niezdolnego do podjęcia decyzji: „Chce pan być uzdrowiony z niewiary i nie zna na to lekarstwa? Niech się pan uczy od tych, którzy pierwej niż pan byli dręczeni zwątpieniem... Trzeba naśladować ich sposób postępowania, czynić wszystko, czego wymaga wiara, tak jakby pan już wierzył. Trzeba chodzić na Mszę Św., używać wody święconej itd. - to pana bez wątpienia uczyni prostym i doprowadzi do wiary". ${ }^{29}$

Święta Teresa z Avila wydaje się wiązać z wodą święconą także duchową pociechę, pokrzepienie, wewnętrzne odnowienie: „Co do mnie, szczególną i bardzo żywą czuję w głębi duszy pociechę, ile razy jej użyję. Najczęściej, szczerze mówię, czuję od niej jakieś odnowienie wewnętrzne, którego opisać nie zdołam, połączone z taką przyjemnością duchową, że cała dusza moja bierze z niej pokrzepienie. Nie jest to żadne przewidzenie ani rzecz, która by raz tylko mi się zdarzyła; doznałam tego bardzo często i za każdym razem z pilną uwagą nad tym się zastanawiałam. Jest to tak, przypuśćmy, jak gdy kto mocno zgrzany i spragniony wypije szklankę zimnej wody i w całym ciele czuje przyjemne stąd orzeźwienie. Zastanawiam się tu nieraz nad tym charakterem wielkości, jaki nosi na sobie wszystko, cokolwiek Kościół postanowił, i raduję się w duchu, gdy wspomnę na tę potężną skuteczność jego słów, jak i te wymówione nad wodą,

28 Por. Agenda liturgiczna diecezji opolskiej. Nabożeństwa, poświęcenia i błogostawieństwa, Opole 1985, s. 435. Niestety, w nowszym rytuale: Obrzędy błogosławieństw dostosowane do zwyczajów diecezji polskich, t. 2, Katowice 2004, s. 128-132, nie znajdziemy modlitwy poświęcenia soli.

29 J. R a t z i n g e r, Wprowadzenie w chrześcijaństwo, Kraków 1996, s. 165. 
taką w niej cudowną sprawiające odmianę i taką dziwną różnicę między wodą święconą a wodą zwyczajną"30.

\section{Znak błogosławieństwa rodziców}

Joseph Ratzinger z wielką wdzięcznością wspomina o błogosławieństwie, jakiego doświadczał ze strony rodziców: „Nigdy nie zapomnę pobożności i pieczołowitości, z jakimi moi rodzice błogosławili znakiem krzyża nas, swoje dzieci, gdy wychodziliśmy z domu; a gdy żegnaliśmy się na dłużej, rodzice kreślili nam znak krzyża wodą święconą na czole, wargach i piersi. To błogosławieństwo towarzyszyło nam, i wiedzieliśmy, że ono nas prowadzi. Było to unaocznienie modlitwy rodziców, która szła z nami, i wyraz pewności, że opiera się ona na błogosławieństwie Zbawiciela. Błogosławieństwo rodziców było równocześnie swoistym zobowiązaniem nas do nieopuszczania przestrzeni tego błogosławieństwa. Błogosławieństwo jest gestem kapłańskim i w tym znaku krzyża odczuwaliśmy kapłaństwo rodziców, jego szczególną godność i moc". ${ }^{31}$ Kardynał pamięta te błogosławieństwa mimo upływu dziesiątków lat. Było to dla niego przejmujące doświadczenie miłości rodziców, ale także potęgi ich modlitwy. Zachęca, by błogosławienie dzieci przez rodziców na nowo stało się częścią ich codziennego życia, by korzystali z mocy, jaką Chrystus złożył w ich dłonie w sakramencie chrztu.

O możliwości błogosławienia przez ojca lub matkę dzieci udających się w podróż wspomina także bp Józef Wysocki. ${ }^{32}$

\section{Wobec doświadczenia śmierci}

Święta Teresa od Dzieciątka Jezus (†1897) w okresie ciężkiej choroby i zbliżającej się śmierci, przeżywała bardzo silne pokusy

30 Św. Teres a od Jezu s a, Dzieła, t. I (Księga Życia, rozdz. 31, p. 4), s. 389.

31 J. R a t z i n ge r, Duch liturgii, Poznań 2002, s. 164.

32 Por. J. W y s o c k i, Rytuał rodzinny, Włocławek 1999, s. 547. 
zwątpienia, wewnętrzne ciemności, bolesną trwogę. Pewnej nocy poprosiła siostrę opiekującą się infirmerią o skropienie łóżka wodą święconą. Powtarzała: „O, jak bardzo trzeba się modlić za konających! Gdyby wiedziano!"33

Woda święcona odgrywała istotną rolę w zwyczajach pogrzebowych polskiego ludu. W celu ochrony przed działaniem złego ducha i pomocy przy ciężkim konaniu wkładano w dłonie umierającego zapaloną świecę gromniczną i skrapiano go wodą święconą. Czasami przy wyprowadzaniu zwłok z domu rodzinnego do kościoła najstarszy z obecnych lub przyjaciel zmarłego, po zamknięciu trumny, wygłaszał słowa pożegnania, kropiąc obecnych i zmarłego wodą święconą. Niekiedy w czasie pogrzebu niesiono garnuszki ze święconą wodą, które następnie zostawiano przy przydrożnym krzyżu. ${ }^{34}$

W zakonie paulinów w XVII w., przy obrzędzie profesji zakonnej, kładziono kandydata do pokrytej całunem trumny. Śpiew zakonników przypominał, że odtąd całe życie wstępującego ma być przygotowaniem do śmierci. Wszyscy bracia przychodzili przed trumnę nowego zakonnika, kropili go wodą święconą i wołali: „Bracie umarłeś światu, żyjesz Bogu!"35

W Szwajcarii, prawdopodobnie jeszcze w XIX w., przy bramach cmentarnych znajdowały się wielkie naczynia $\mathrm{z}$ wodą święconą, a przy nich kropidła. Wierni korzystali z nich, kropiąc groby zmarłych. Jakie znaczenie ma zwyczaj używania wody święconej w odniesieniu do zmarłych? Przez to pokropienie sami się oczyszczamy i zabezpieczamy przed roztargnieniem w modlitwie za tych, którzy odeszli. W widzialnym znaku wyrażamy nasze pragnienie złagodzenia zmarłym cierpień czyścowych i rychłego wprowadzenia ich do miejsca wiecznej ochłody. ${ }^{36}$ Okazujemy szacunek wobec ludzkiego

33 Św. Teres a od D z i e c i ą t k a J e z u s, Dzieje duszy. Rękopisyautobiograficzne A, B, C. Rady i wspomnienia, Ostatnie rozmowy, Wybór listów, poezji, modlitw, Kraków 1996, s. 277.

34 Por. A. F i s c h e r, Zwyczaje pogrzebowe ludu polskiego, Lwów 1921, s. 67-68, 291, 352.

35 J. I. K r a s z e w s k i, Kordecki. Powieść historyczna, t. I, Wilno 1852, s. 184.

36 Por. J. J. G a u m e, Woda święcona w XIX wieku, s. 332-333. 
ciała, ale także wyrażamy wiarę w tajemnicę czyśćca. Ślady tego zwyczaju w odniesieniu do pojedynczych grobów możemy spotkać na niektórych cmentarzach współczesnej Bawarii.

\section{Woda święcona a pragnienie uświęcenia całego życia}

Kardynał Stefan Wyszyński (†1981), w prośbach ludzi świeckich o udzielenie im przez kapłana różnych błogosławieństw, dostrzega ich pragnienie, by nie tylko sfera sakralna, ale całe ich życie, codzienna egzystencja były w pełni oddane Panu Bogu. W Rytuale Rzymskim widzi program uświęcenia życia doczesnego, a także wezwanie skierowane do kapłana, by pozwolił Bogu przeniknąć głębię również swojego życia: „Wzywany jestem tylekroć do różnych poświęceń, którymi obfituje Rytuał, i uświadamiam sobie, jak ludzie świeccy czuwają nad tym, aby całe ich życie było w imię Boże prowadzone". ${ }^{37}$ Wyraźnie widoczny jest tu związek między sakramentaliami, a powołaniem ludzi świeckich do świętości.

Sakramentalia stanowią wyraz troski Kościoła o codzienne życie człowieka, by je uduchowić, uświęcić, uczynić miejscem pogłębiania jedności z Bogiem. ${ }^{38}$

Według J. Ratzingera woda święcona nie jest elementem sprzecznym z posoborową duchowością. Nierzadko jest o niej mowa w objawieniach maryjnych uznanych przez Kościół. Wskazuje ona na znaczenie ludzkiego ciała w drodze do zbawienia. Można dostrzec tutaj zgodność z nauczaniem II Soboru Watykańskiego o ludzkim ciele jako inkarnacji Ducha. ${ }^{39} \mathrm{~W}$ miejscach prywatnych objawień Matki Bożej często występują uświęcone źródła, w których Bóg przez wodę nierzadko uzdrawia choroby duszy i ciała. Tak dzieje się np. w Lourdes, gdzie każdego roku przybywają miliony pielgrzymów,

37 S. W y s z y ń s k i, List do moich kapłanów, Ząbki 2010, s. 391.

38 Por. S. W i t e k, Teologia życia duchowego, Lublin 1986, s. 342.

39 Por. Raport o stanie wiary. Rozmowa Vittorio Messoriego przeprowadzona w 1984 roku z ks. kardynałem Josephem Ratzingerem - prefektem Kongregacji Nauki Wiary - obecnym papieżem Benedyktem XVI, Marki 2005, s. 101. 
z których wielu zanurza się w basenach z wodą z lourdskiego źródła, wierząc w możliwość uzdrowienia zarówno zewnętrznego, jak i wewnętrznego.

Gerhard Ludwig Müller podkreśla, że sakramentalia, wśród których wymienia też wodę święconą, pełnią doniosłą rolę w antropologicznej konkretyzacji wiary i dlatego zasługują na nasz szacunek. ${ }^{40}$

W dziewiętnastowiecznej Polsce woda święcona była obecna $\mathrm{w}$ domach wiernych przy drzwiach lub w innym miejscu. Wierni mogli kropić nią siebie i swoje mieszkania w czasie doznawanej pokusy czy innego niebezpieczeństwa, przed rozpoczęciem modlitwy, przy udawaniu się na spoczynek i przy wstawaniu. ${ }^{41}$ Proboszcz z Ars, Jan Maria Vianney, mówi o penitentach spowiadających się z zaniedbania dotyczącego opuszczenia przeżegnania się wodą święconą rano i wieczorem. Przystępujący do sakramentu pokuty uważali to zaniedbanie za grzech lekki. ${ }^{42}$ Michał Sopoćko również wymienia wśród sakramentaliów wodę święconą i zachęca do codziennego z niej korzystania: „Będę cenił sakramentalia. Będę czuwał, by w pokoju nad łóżkiem była kropielniczka z wodą święconą, którą pobożnie będę się żegnał, kładąc się do snu i wstając". ${ }^{43}$

O znaczeniu wody święconej jako sakramentalium dla prostego ludu świadczy m.in. powstanie, jakie wybuchło w szesnastowiecznej Anglii. Ludność wiejska zachodnich prowincji, szczególnie Kornwalii, Devon i Essex, rozpoczęła w 1549 r. wielkie powstanie w obronie religii katolickiej zagrożonej przede wszystkim w wyniku promulgowania Księgi Modlitwy Powszechnej. Wśród żądań skierowanych

40 Por. G. L. M ü 11 e r, Dogmatyka katolicka, Kraków 2015, s. 654.

${ }^{41}$ Por. B. A r c i s z e w s k i, Wykład historyczny i moralny świąt, obrzędów, zwyczajów Kościoła Katolickiego, Lwów 1852, s. 348.

42 Por. J. L a s k ow s k i (wybór i oprac.), Kazania proboszcza z Ars, Warszawa 2008, s. 183.

${ }^{43}$ M. S o p o ć k o, Miłosierdzie Boga w dziełach Jego, t. III: Duch Święty, Kościól, łaska, cnota, dary Ducha Świętego, modlitwa, ufność, sakramenty święte, Rzym-Paryż-Londyn 1962, s. 202. 
do króla Edwarda VI znalazło się także stwierdzenie: „Chcemy, aby opłatki i woda święcona była rozdawana każdej niedzieli..."44

W niektórych rejonach Polski rolnicy, rozpoczynając siewy, kropili swoje ręce wodą święconą. Pierwszą garść ziarna rzucali w formie znaku krzyża. ${ }^{45} \mathrm{~W}$ Wielką Sobotę przynosili wodę święconą do domów, spożywali ją, a także kropili nią zwierzęta i drzewa w sadzie. ${ }^{46}$ Ten ostatni zwyczaj występuje nadal w wielu rodzinach.

Święta Josemaria Escriva de Balaguer $(\dagger 1975)$ z naciskiem poleca codzienne używanie wody święconej. ${ }^{47}$ George Kelly przypomina, że w krajach katolickich istnieje zwyczaj umieszczania naczynia z wodą święconą przy wejściu do domu, dzięki czemu wchodzący i wychodzący mogą przeżegnać się i prosić o Boże łaski. Zachęca, by podobny obyczaj wprowadzić w Stanach Zjednoczonych. ${ }^{48}$

Obecność wody święconej w domach wiernych jest zwyczajem nie tylko katolików. Wierni prawosławni na początku wieczerzy wigilijnej spożywają kawałek prosfory, żegnają się i piją łyk święconej wody. W święto Objawienia Pańskiego (19 stycznia) prawosławni duchowni święcą wodę w studniach i rzekach. Wierni zabierają ją do domów i przechowują przez cały rok, używając $\mathrm{W}$ razie potrzeby. ${ }^{49}$

44 Por. G. K u c h a r c z y k, Czerwone karty Kościoła, Poznań 2002, s. 26.

45 Por. W. Z a le s k i, Rok kościelny. Święta Pańskie, Matki Bożej, Apostołów, Świętych i Błogosławionych Polskich oraz dni okolicznościowe, t. 2, Warszawa 1993, s. 333.

46 Por. W. R e y m o n t, Chłopi, t. III: Wiosna, rozdz. IV, Warszawa 2000, s. 80.

47 Por. św. J o s e m a r i a E s c r i v a, Droga, nr 572, Poznań 2012, s. 136-137.

48 Por. G. A. Ke 11 y, Poradnik rodziny katolickiej, Sandomierz 2007, s. 352.

49 Istnieje świadectwo z VI w. błogosławienia wody w Jordanie podczas święta Objawienia Pańskiego. Poświęcona woda była zabierana w dzbanach i służyła do pokropienia statków wyruszających w morze; por. P. I w a s z k i e w i c z (oprac.), Do Ziemi Świętej. Najstarsze opisy pielgrzymek do Ziemi Świętej IV-VIII w., Kraków 2010, s. 213 (Itinerarium Anonymi Placentini 11). 


\section{Niebezpieczeństwa i ograniczenia}

Papież Pius IX zauważa niebezpieczeństwo korzystania z wody święconej bez właściwej postawy człowieka wobec Boga: ,...im większa konieczność używania tego zbawiennego środka nagli, tym coraz, niestety, rzadziej do niego się uciekają lub bez należytej pobożności używają". ${ }^{50}$ Chrześcijanie powszechnie używają wody święconej, przynajmniej żegnając się przy wejściu do świątyni. Często jednak czynią to machinalnie, mechanicznie, bezmyślnie. Wówczas, niestety, brakuje szacunku dla tego Bożego daru.

Kardynał Stefan Wyszyński w jednym ze swoich kazań (14 XII 1949 r.) przypomina rodzicom o potrzebie podjęcia wysiłku chrześcijańskiego wychowania swoich dzieci: „W środowisku chrześcijańskiego domu, w którym nie braknie krzyża, obrazów świętych, wody święconej i gromnicy, rozpoczyna się także katolickie wychowanie, zasilane pracą i modlitwą" ${ }^{51}$ Nie wystarczy sama woda święcona. Niezbędna jest codzienna, wytrwała i głęboko przemyślana praca.

Święta Teresa od Jezusa z wielkim bólem pisze o chrześcijanach, którzy lekceważą grzechy powszednie, bo jak mówią, jest przecież od tego woda święcona i inne lekarstwa podane przez Kościół. ${ }^{52}$ Człowiek może przyjąć prawdę o wodzie święconej w sposób zdeformowany, rezygnując z duchowej walki, ze zmagania z własnymi wadami, z wysiłku współdziałania z łaską Bożą.

Ksiądz Pałyga pisze krytycznie o osobach, które odmawiają skorzystania z konsultacji psychologicznej, próbując niejako na skróty rozwiązać swoje złożone psychiczne i duchowe problemy. Szukają

50 P i u s IX, List do księdza Gaume, 14 marca 1866, Rzym, w: J. J. G a u m e, Woda święcona w XIX wieku, s XI-XII.

${ }^{51} \mathrm{~S}$. W y s z y ń s k i, Pouczenie pasterskie o sakramencie matżeństwa na dzień Świętej Rodziny, 14 grudnia 1949, w: t e n ż e, Dzieła zebrane, t. I: 1949-1953, Warszawa 1991, s. 70.

52 Por. Św. Te r e s a o d J e z u s a, Dzieła, t. III, Kraków 1995, s. 113 (Podniety Miłości Bożej, rozdz. 2, p. 20). 
oni pomocy u samozwańczych uzdrowicieli, wróżbitów czy egzorcystów i wydają się wierzyć nie tyle w Boga, ile w wodę święconą. ${ }^{53}$

Ksiądz Michał Sopoćko ostrzega przed niebezpieczeństwem nadużyć w korzystaniu z sakramentaliów: „Zaznaczyć trzeba, że użycie sakramentaliów o tyle jest godziwe, o ile ma na względzie cześć Boga i nie przypisuje się im skutku innego, aniżeli one mają. Inaczej bowiem mogą się stać niegodziwym zabobonem i kuszeniem Pana Boga, np. przypisywanie pewnej czynności lub określonej ilości modlitw - jakiegoś specjalnego, nadzwyczajnego skutku". ${ }^{54}$ Istnieje zagrożenie, że wierni zapomną, iż w sakramentaliach Kościół prosi Boga o skutek, przyzywając Jego miłosierdzia, a potraktują sakramentalia jako środek zbliżony do magicznego.

We współczesnej Polsce błogosławieństwa kapłana - przy okazji otwierania dróg, mostów lub innych wielkich inwestycji państwowych czy samorządowych - często spotykają się z krytyką. Wielu odbiera te wydarzenia jako uczestnictwo Kościoła w manipulacjach polityków dążących do zwiększenia wyborczego poparcia.

Oczywiście woda święcona nie działa własną mocą. To Bóg działa przez ten zewnętrzny znak.

We współczesnej teologii wyraźnie odróżnia się sposób działania sakramentaliów od sakramentów. Sakramentalia nie działają ex opere operato, lecz na sposób moralny, ex opere operantis, na mocy wartości, doskonałości i zasług Kościoła oraz osoby dokonującej lub przyjmującej dane sacramentale, a więc mają charakter raczej prośby, intencji, modlitwy. ${ }^{55}$ Pojawia się tutaj jednak pewna trudność. W tradycji Kościoła powszechnie uznawano, że błogosławieństwa wody święconej dokonuje ważnie i czyni ją skuteczną także grzeszny kapłan. Być może należałoby mocniej zaakcentować znaczenie zasług Kościoła i świętych. Wodą święconą posługiwali się wielcy święci

53 Por. J. P ał y g a, Upadek i nadzieja. Twarze ludzkiej niedoli, Ząbki 2003, s. $65-66$.

54 M. S o p o ć k o, Miłosierdzie Boga w dziełach Jego, s. 200.

55 Por. Cz. B a r t n i k, Dogmatyka katolicka, t. 2, Lublin 2003, s. 664. 
przez całe stulecia. Traktowali ją jako jeden ze środków pomagających w drodze do Boga, ale obejmowali ją także swoją modlitwą.

\section{Przyczyny odrzucenia}

Niekiedy księża odnoszą się z lekceważeniem do wody święconej, nie traktując poważnie oczekiwań i potrzeb wiernych. Zdarzają się kościoły, np. w Austrii, w których nie ma już kropielnicy z wodą święconą przy drzwiach wejściowych, a kapłan, na zwróconą uwagę, odpowiada, że nie zamierza ulegać głupiej modzie. Czasem duchowni widzą w wodzie święconej zwyczaj należący do przeszłości, nie mający znaczenia dla współczesnego człowieka, nie wywierający wpływu na przekaz wiary nowym pokoleniom.

Woda święcona spotyka się nierzadko z silną krytyką ludzi znajdujących się poza Kościołem katolickim, dla których stanowi ona przykład ulegania przez Kościół tendencjom pogańskim, magii czy prądom antyracjonalistycznym.

Romano Guardini (†1968) wydaje się dostrzegać problem przytępiającej duszę kultury miejskiej. Ulegając jej, człowiek przestaje dostrzegać istnienie i działanie szatana. Ten wybitny niemiecki teo$\log$ XX w. uważa za zupełnie oczywiste przeżegnanie się wodą święconą na rozpoczęcie czy zakończenie dnia: „Gdy gaśnie światło dnia i światło świadomości, człowiek, poddając się mocy snu i mroku, zwykł żegnać się znakiem krzyża św. i wodą święconą, symbolem wyzwolonej, oczyszczonej od grzechów natury, mówiąc tym samym: «Niech mnie Bóg strzeże od wszystkiego, co ciemne!»" ${ }^{56}$

$$
* * *
$$

Woda święcona może stanowić pomoc w życiu człowieka świeckiego dążącego do świętości. Przypomina o otrzymanym sakramencie chrztu, zachęcając do wdzięczności Bogu za tak wielki dar, do radości i poczucia chrześcijańskiej dumy. Pomaga w przygotowaniu

56 R. G u a r d i n i, Znaki święte, Wrocław 1987, s. 49. 
do Eucharystii przez uświadomienie sobie Bożej obecności. Przez wodę święconą Bóg odpuszcza grzechy powszechnie, gdy korzystamy z niej w postawie skruchy. Woda ta stanowi element błogosławieństwa, którego udzielają rodzice swoim dzieciom mocą kapłaństwa wypływającego z tajemnicy chrztu. Odgrywa istotną rolę w chrześcijańskich zwyczajach pogrzebowych, wskazując na szczególne znaczenie chwili śmierci człowieka, godność ludzkiego ciała, tajemnicę czyśćca, znaczenie modlitwy za zmarłych. Woda święcona używana w błogosławieństwach wskazuje na potrzebę uświęcenia całego życia doczesnego, ludzkiej codzienności, różnych wymiarów ludzkiej pracy i aktywności. Niekiedy jest ona przechowywana w domach wiernych, gdzie może stanowić pomoc w chwili przeżywanej pokusy. Wielu świętych wskazuje na znaczenie wody święconej jako obrony przed działaniem złego ducha. Korzystanie z niej może łączyć się z pociechą, umocnieniem w walce duchowej, odnowieniem wewnętrznym. Występuje jednak także niebezpieczeństwo nadużyć: korzystanie mechaniczne, rezygnacja $z$ duchowej walki z grzechami powszednimi, zaniedbanie codziennych obowiązków, rozumienie magiczne.

$$
\text { Grzegorz BACHANEK }
$$

Słowa kluczowe: woda święcona, woda pobłogosławiona, powszechne kapłaństwo wiernych, wierni świeccy, sakrament chrztu, charakter sakramentalny, woda

Keywords: holy water, blessed water, universal priesthood of the faithful, lay people, sacrament of baptism, sacramental character, water

\section{Holy water (blessed water) as the reflection of the universal priesthood of the faithful}

Summary

Holy water can help lay people in their pursuit of sainthood. It reminds them about the sacrament of baptism and encourages to be grateful to God for such a great gift, to feel joy and pride in being Christian. It helps to 
prepare for the Eucharist and raises awareness God's presence. Through holy water God absolves the venial sins when we use it in the spirit of remorse. This water constitutes an element of the blessing which is given by parents to their children on the basis of priesthood arising from the mystery of baptism. It plays an important role in the Christian customs related to burial, indicating the exceptional meaning of human death, the dignity of the human body, the mystery of the purgatory and the significance of the prayer for the dead. Holy water is used in blessings and shows the need to sanctify the whole human life, the everyday existence, the various dimensions of human labour and activity. Sometimes it is kept in the houses of the believers to which they can resort to in moments of temptation. Many saints talks of the importance of holy water as protection from the evil spirit. Furthermore, it provides consolation, reassurance in spiritual struggle and internal renewal. There is also the danger of abuse: mechanical use, giving up the spiritual struggle with venial sins, neglecting everyday duties, magical thinking. 